\title{
Research on Insecure Impact of Inflation upon Capital Structure
}

\author{
Chunlin $\mathrm{Li}^{1}$ and Ming Zhang ${ }^{2}$ \\ ${ }^{1}$ Shanghai University of Engineering Science, Shanghai 201620, China \\ ${ }^{2}$ Management Institute, Donghua University, Shanghai 200051, China
}

\begin{abstract}
The inflation often causes insecure impact on the capital structure, and the inflation is used as an important indicator of the economy state. To analyze the insecure impact of the inflation, an analysis model is proposed to reflect the inflation's effect on the capital structure of the company, in this paper. We use the parameter CPI to measure the inflation. Because the inflation is a time series that affects the capital structure for a long time, we choose different CPIs for different time, i.e. the current month (CPI), three months ago (CPI3), six months ago (CPI6), one year ago (CPI12), half and one year ago (CPI18), and two years ago (CPI24). With the financial data of the companies listed in the Chinese stock market, we empirically testified the outcomes of this model. The results of this analysis show that only the increasing inflation or the decline of corporate income tax rate will increase the company's debt ratio. However, these two factors together will decrease the debt level of the company and cause the insecure financial impact.
\end{abstract}

Keywords: Inflation; Capital structure; Corporate income tax; Security

\section{Introduction}

The capital structure theory is usually the central issue of the corporate finance. In 1958, Miller Modigliani proposed the MM theory, which is the seed paper for the modern financial theory [1]. Based on the MM theory, Miller discussed the personal income tax's effect on the financial structure in 1977 [2]. Then the trade-off theory found the debt interest was a tax shield, and the increasing debt brought an increasing number of reduced corporate income tax. Afterward, the agent theory, the signal theory, the financing order theory and the financing timing theory all explained the capital structure in various aspects [3-10]. However, these researches usually focused on the microeconomic agent behaviors and they rarely considered the macroeconomic effect especially of the inflation on the capital structure.

The inflation is an important indicator to measure the state of the economy, which is the general price level in a given period [11-15]. Since the 1980s, China has reformed and changed gradually from the planned economy to the socialist market economy with some Chinese characteristics. However, there have been several significant fluctuations in the economy in the transition process along with several serious inflations. The ways that the companies adjusted their capital structures in response to inflation are the basis for the analysis of the overall economic financial risks triggered by the inflation. This also helped the government make the right policy. In this paper, the theoretical models and the empirically analysis are used to examine the impact of the inflation and the changes in the income tax on the capital structure from the macroeconomic perspective.

With some security inspired approach [16-17], to analyze the insecure impact of the inflation, we built an analysis model to reflect the inflation's effect on the capital structure of the company, in this paper. We use the different parameters to measure the inflation, according to the time series, which affects the capital structure for a long time. Section 2 designed our model of the inflation's effect on the capital structure. Section 3 analyzed our model according to some experience and hypothesis. Section 4 gave some results by a series of calculation. 


\section{Analysis Model of Inflation's Effect on Capital Structure}

Assume that a company has equipments and technical productions and the impact demand of the market is the following Wiener process.

$$
\frac{d X_{t}}{X_{t}}=\mu d t+\sigma d W
$$

Here, $X_{t}$ is the impact market demand; $\mu$ is the expected increased ratio; $\sigma$ is the volatility of impact market demand, and $d W$ follows the Normal distribution.

Moreover, the product market demand is calculated below.

$$
D=\left(p / X_{t}\right)^{\frac{1}{\alpha-1}} \alpha \in[0,1)
$$

Here, $D$ represents the market demand at time ${ }^{t} ; p_{\text {is product price; }} X_{t}$ is the impact market demand; and $\alpha$ means this is a fixed demand function. Equation (2) means that the impact of demand increases the market demand, but the higher price will decrease the market demand.

The company is monopoly and the current investment is $K$, with which the company would fulfill the market demand. If one investment would produce one unit, according to the microeconomic theory, in equilibrium the price of the product should be:

$$
p=X_{t} K^{\alpha-1}
$$

So the revenue equals the product of the price and the output.

$$
p K=X_{t} K^{\alpha}
$$

The optimal financing strategy is raising the appropriate debt whose interest just equals the revenue. In this way, the company's tax duty is free. With equation (4), the debt interest is equal to the $X_{t} K^{\alpha}$ 。

If the company's current investment is $K_{0}$, the value of the company $V\left(X_{t}, K_{0}\right)$ should equal the expected present value of all after-tax revenue $\left(1-\tau_{i}\right) X_{t} K_{0}^{\alpha}$, in which $\tau_{i}$ represents tax rate of the $i$ th period. If $r$ is the risk free interest rate, then the value of the company is calculated below.

$$
V\left(X_{t}, K_{0}\right)=E_{t} \int_{t}^{\infty} e^{-r\left(1-\tau_{i}\right) s}\left(1-\tau_{i}\right) X_{s} K_{0}^{\alpha} d s
$$

According to the Fubini Theory, the following formula is calculated.

$$
E_{t}\left[\int_{t}^{\infty} e^{-r\left(1-\tau_{i}\right) s}\left(1-\tau_{i}\right) X_{s} K_{0}^{\alpha} d s\right]=\left(1-\tau_{i}\right) X_{t} K_{0}^{\alpha} \int_{t}^{\infty} e^{-r\left(1-\tau_{i}\right) s} d s=\frac{\left(1-\tau_{i}\right) X_{t} K_{0}^{\alpha}}{r\left(1-\tau_{i}\right)-\mu}
$$

With the equations (5) and (6), the following formula is calculated.

$$
V\left(X_{t}, K_{0}\right)=\frac{\left(1-\tau_{i}\right) X_{t} K_{0}^{\alpha}}{r\left(1-\tau_{i}\right)-\mu}
$$


If the company could adjust its capital structure, the optimal debt should equal the present value of all revenue with investment $K_{0}$. Therefore, the debt value $D\left(X_{t}, K_{0}\right)$ should be:

$$
D\left(X_{t}, K_{0}\right)=E_{t}\left[\int_{t}^{\infty} e^{-r\left(1-\tau_{i}\right) s}\left(1-\tau_{i}\right) X_{t} K_{0}^{\alpha} d s\right]=\frac{\left(1-\tau_{i}\right) X_{t} K_{0}^{\alpha}}{r\left(1-\tau_{i}\right)}=\frac{X_{t} K_{0}^{\alpha}}{r}
$$

If the equation (7) is transformed into the equation (8), we can get the optimal capital structure below.

$$
L R_{t}=\frac{D\left(X_{t}, K_{0}\right)}{V\left(X_{t}, K_{0}\right)}=\frac{r\left(1-\tau_{i}\right)-\mu}{r\left(1-\tau_{i}\right)}
$$

After the static analysis, the following two conclusions are drawn.

(1) $\frac{\partial L R_{t}}{\partial r}>0$ means that the higher risk free interest would increase the debt ratio. Usually the inflation would push the risk free interest upward, so the inflation eventually will increase the company's debt ratio.

(2) $\frac{\partial L R_{t}}{\partial \tau}<0$ means that the higher tax rate $\tau$ would decrease the debt ratio.

\section{Empirical Analysis}

According to the above analysis, we take the following original hypothesis.

$H O$ : the debt ratio is positively correlated with inflation, but negatively correlated with the income tax ratio.

We take the debt ratio as the dependent variable Zcfzl.

For the independent variables, we use the CPI to measure the inflation. Because the inflation is the time series that impacts the capital structure for a long time, we choose different time, such as the current month (CPI), three month ago (CPI3), six month ago (CPI6), one year ago (CPI12), half and one year ago (CPI18), and two years ago (CPI24).

Ldbl represents the current ratio and is calculated below.

$\mathrm{Ldbl}=($ current asset $) /($ current debt $)$

Yyzzl $=($ current period turnover - last period turnover $) /($ current period turnover $)$

Qbzcsh $=($ Net cash flow from operating activities $) /($ total asset $)$

Mgsy $=$ (net profit) $/$ (stock shares)

$$
\text { Yymll }=(\text { turnover }- \text { cost }) /(\text { turnover })
$$

Zcbcl $=($ net profit + interest $) /($ total asset $)$

Zbmjd $=($ total asset $) /($ turnover $)$

Zczl represents the control variable and is calculated below.

$\mathrm{Zczl}=\log ($ total asset $)$ 
Sdsbd is dummy variable. For example, because the income tax rate is reduced $25 \%$ in 2008, Sdsbd is 0 before 2008 and after 2008 Sdsbd is 1.

Jcbl is the interaction of inflation and the tax rate is calculated below.

$$
\mathrm{Jcbl}=\mathrm{Sdsbd} \times \mathrm{CPI} 12
$$

For the sample data, we take 955 company listed in Chinese stock market in September 2003 as the samples. The time is between Sep. 302003 and Sep 30 2012., and the data are from the CSMAR database.

So the empirical model is built blow.

$$
\begin{aligned}
\mathrm{Zcfzl} & =\beta_{0}+\beta_{1} \mathrm{CPI}+\beta_{2} \mathrm{CPI} 3+\beta_{3} \mathrm{CPI} 6+\beta_{4} \mathrm{CPI} 12+\beta_{5} \mathrm{CPI} 18+\beta_{6} \mathrm{CP} 24+\beta_{7} \mathrm{Ldbl} \\
& +\beta_{8} \mathrm{Yyzzl}+\beta_{9} \mathrm{Qbzcsh}+\beta_{10} \mathrm{Mgsy}+\beta_{11} \mathrm{Yymll}+\beta_{12} \mathrm{Zcbcl}+\beta_{13} \mathrm{Zbmjd} \\
& +\beta_{14} \mathrm{Zczl}+\beta_{15} \mathrm{Sdsbd}+\beta_{16} \mathrm{Sdsbd} \times \mathrm{CPI} 12
\end{aligned}
$$

\section{Empirical Calculation Results}

We use the panel data method to analyze the samples and the outcome is shown in Table 1.

Table 1. The Inflation's Impact on the Capital Structure

\begin{tabular}{|c|c|c|c|c|}
\hline Zcfzl & Coef. & Std.Err. & $\mathrm{t}$ & $\mathrm{P}>|\mathrm{t}|$ \\
\hline CPI & .0076739 & .0009621 & 7.98 & 0.000 \\
\hline CPI3 & -.0001985 & .0012002 & -0.17 & 0.869 \\
\hline CPI6 & -.004034 & .0010815 & -3.73 & 0.000 \\
\hline CPI12 & .0105633 & .0011941 & 8.85 & 0.000 \\
\hline CPI18 & -.0034064 & .0008481 & -4.02 & 0.000 \\
\hline CP24 & .0073297 & .000726 & 10.10 & 0.000 \\
\hline Ldbl & -.0800267 & .0009264 & -86.39 & 0.000 \\
\hline Yyzzl & $8.56 \mathrm{e}-07$ & $5.38 \mathrm{e}-06$ & 0.16 & 0.874 \\
\hline Qbzcsh & -.287261 & .0142611 & -20.14 & 0.000 \\
\hline Mgsy & -.0400563 & .0049737 & -8.05 & 0.000 \\
\hline Yymll & .0000353 & .0000591 & 0.60 & 0.550 \\
\hline Zcbcl & -.4086738 & .0260142 & -15.71 & 0.000 \\
\hline Zbmjd & $6.85 \mathrm{e}-07$ & $1.52 \mathrm{e}-07$ & 4.51 & 0.000 \\
\hline Zczl & -.064657 & .0023388 & -27.65 & 0.000 \\
\hline Sdsbd & .3884468 & .0982262 & 3.95 & 0.000 \\
\hline Sdsbd×CPI12 & -.0033598 & .0009567 & -3.51 & 0.000 \\
\hline cons & -.5661604 & .1438223 & -3.94 & 0.000 \\
\hline
\end{tabular}

From Table 1, the different period CPI has different impact on the capital structure. The current month CPI, one year ago CPI and two year ago CPI are positively correlated with the debt ratio. However, three month ago CPI, six month ago CPI and half and a year ago CPI have the opposite effects. Usually the inflation is persistent rising. With the different periods together, we found the coefficient of the positive effect is higher 
than that of the negative effect. In this way, the CPI can increase the debt ratio, which confirms the hypothesis.

Another confirmation is the declined income tax rate with the positive debt ratio. When the income tax rate is $25 \%$, the overall company's debt ratio increased. However, the Jcbl is negative, which means the inflation with the declined income tax rate will reduce the tax ratio.

The variable Ldbl is negatively correlated with the debt ratio, because the higher is the ratio, the less is the current debt as well as the debt ratio. The variables Mgsy and Qbzcsh are negatively correlated with the debt ratio too. If the company can make more net profit or net operating cash, it will depend less on the outside financing. The variable Zcbcl also has negative effect on the debt ratio, for the company with the weak capacity to generate profit has to depend on the debt.

The variables Yyzzl and Yymll statistically affect the capital structure, which means that the gross margin and the turnover change cannot affect the debt ratio.

\section{Conclusion}

We proposed the above analysis model to reflect the inflation's effect on the capital structure of the company. With the listed companies' financial data in the Chinese stock market, we empirically testified the model's outcomes. The study showed that only the increasing inflation or the declined corporate income tax rate will respectively improve the company's debt ratio. However, these two factors together would decrease the debt level of the company and make the financial state of the company insecure.

\section{References}

[1] F. Modigliani and M. H. Miller, "The Cost of Capital, Corporate Finance, and the Theory of Investment", American Economic Review, vol. 48, no. 2, (1958), pp. 178-197.

[2] M. H. Miller, "Debt and Taxes", The Journal of Finance, vol. 32, no. 2, (1977), pp. 261-275.

[3] M. C. Jensen and W. H. Meckling, "Theory of the Firm: Managerial Behaviour, Agency Costs and Ownership Structure", Journal of Financial Economics, vol. 3, no. 4, (1976), pp. 305-360.

[4] S. C. Myers and N. Majluf, "Corporate financing and investment decisions when firms have information that investors do not have", Journal of Financial Economics, vol. 13, no. 2, (1984), pp. 187-221.

[5] M. Bittencourt, R. Gupta and L. Stander, "Tax evasion, financial development and inflation: Theory and empirical evidence", Journal of Banking \& Finance, vol. 41, (2014), pp. 194-208.

[6] B. Russell and R. A. Chowdhury, "Estimating United States Phillips curves with expectations consistent with the statistical process of inflation", Journal of Macroeconomics, vol. 35, (2013), pp. 24-38.

[7] G. Carboni and M. Ellison, "Inflation and output volatility under asymmetric incomplete information", Journal of Economic Dynamics \& Control, vol. 35, no. 1, (2011), pp. 40-51.

[8] D. Pfajfar and E. Santoro, "Heterogeneity, learning and information stickiness in inflation expectations", Journal of Economic Behavior \& Organization, vol. 75, no. 3, (2010), pp. 426-444.

[9] K. Lahiri and X. G. Sheng, "Learning and heterogeneity in GDP and inflation forecasts", International Journal of Forecasting, vol. 26, no. 2, (2010), pp. 265-292.

[10] M. Lines and F. Westerhoff, "Inflation expectations and macroeconomic dynamics: The case of rational versus extrapolative expectations", Journal of Economic Dynamics \& Control, vol. 34, no. 2, (2010), pp. 246-257.

[11] M. Zhang and T. Gong, "Research on Secure Corporate Investment against Inflation Impact", International Journal of Security and Its Applications, vol. 7, no. 4, (2013), pp. 91-96.

[12] D. Nazar, P. Farshid and K. Z. A. Mojtaba, "Asymmetry effect of inflation on inflation uncertainty in Iran: Using from EGARCH model, 1959-2009”, American Journal of Applied Sciences, vol. 7, no. 4, (2010), pp. 535-539.

[13] H. M. Ennis, "Search, money, and inflation under private information", Journal of Economic Theory, vol. 138, no. $1,(\mathbf{2 0 0 8})$, pp. 101-131.

[14] T. E. Cone, "Information technology and the welfare cost of anticipated inflation", Computational Economics, vol. 30, no. 1, (2007), pp. 1-18.

[15] B. Heer and B. Suessmuth, "Effects of inflation on wealth distribution: Do stock market participation fees and capital income taxation matter?” Journal of Economic Dynamics \& Control, vol. 31, no. 1, (2007), pp. 277-303.

[16] C. M. Chen, Y. H. Lin and Y. H. Chen, et al., "SASHIMI: Secure Aggregation via Successively Hierarchical Inspecting of Message Integrity on WSN", Journal of Information Hiding and Multimedia Signal Processing, vol. 4, no. 1, (2013), pp. 57-72. 
[17] C. W. Lin, T. P. Hong and C. C. Chang, et al., "A Greedy-based Approach for Hiding Sensitive Item sets by Transaction Insertion", Journal of Intelligent Information Hiding and Multimedia Signal Processing, vol. 4, no. 4, (2013), pp. 201-227.

\section{Author}

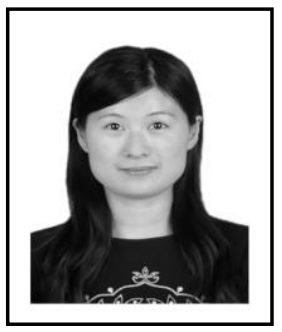

Chunlin Li, is a lecturer at Shanghai University of Engineering Science. Her research interests include Industrial Economy, finance, cloud computing, education technology, etc. 